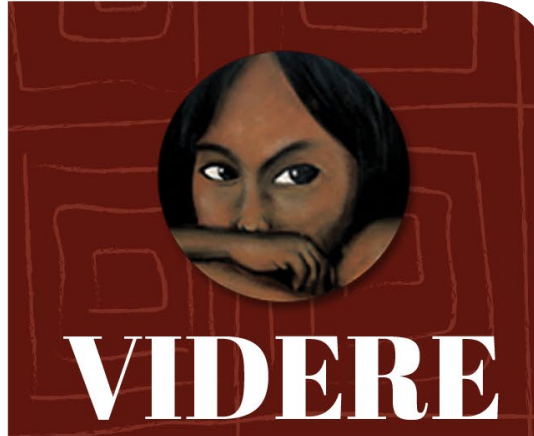

V. 13, N. 28, SET.DEZ. 2021 ISSN: $2177-7837$

Recebido: 13/08/2021. Aprovado: 10/10/2021.

\section{Páginas: 185-215.}

DOI: $10.30612 /$ videre. v13i28.13154

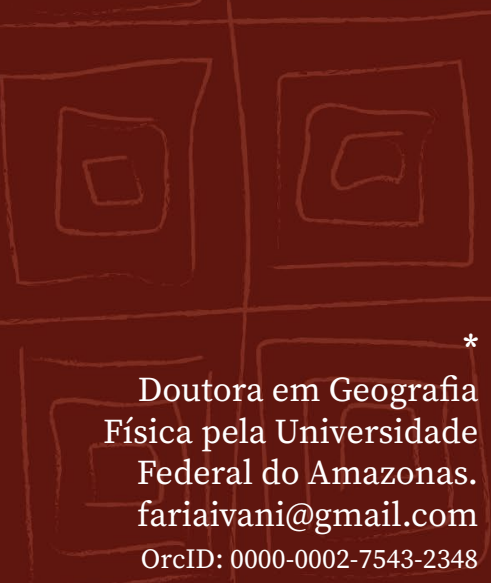

$* *$

Doutoranda em Ciências do Ambiente e Sustentabilidade na Amazônia pela

Universidade Federal do Amazonas. carla.cetina@hotmail.com OrcID: 0000-0003-3220-860X

$* * *$

Doutorando em

Biotecnologia pela

Universidade Federal do

Amazonas.

diego.ecologo@gmail.com OrcID: 0000-0002-0498-6917

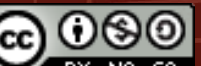

\section{Conflitos} territoriais, autonomia e o direito do povo mura à consulta prévia, livre e
informada

Territorial conflicts, autonomy and the right of the mura people to prior, free and informed consultation

Conflictos territoriales, autonomía y el derecho del pueblo mura a la consulta previa, libre e informada

\author{
Ivani Ferreira de Faria* \\ Carla Cetina Castro ${ }^{* *}$ \\ Diego Ken Osoegawa ${ }^{* * *}$
}

\section{Resumo}

Esse artigo visa compartilhar a experiência da realização da Assembleia sobre à Consulta Prévia, Livre e Informada junto ao povo Mura. Originou-se dentro do processo judicial a partir de uma Ação impetrada pelo Ministério Público Federal diante das denúncias do povo Mura contra atividades do empreendimento de exploração de silvinita denominado Projeto Potássio Autazes/Amazonas, sem previamente ter realizado CPLI. Pretende-se demonstrar a importância dessa discussão que antecedeu a elaboração do Protocolo de Consulta e Consentimento Livre, Prévio e Informado. Tal discussão pode servir para definir previamente os instrumentos, planejamentos e principalmente, a metodologia usada fundamentada na participação, autonomia e organização social, política e cultural dos povos indígenas. Os Mura decidiram elaborar o PCCLPI antes da realização da CPLI, definiram a metodologia para a elaboração do protocolo e ampliaram o número de Terras e aldeias que seriam consultadas extrapolando os limites do município de Autazes, incluindo terras regularizadas e sem providência.

Palavras-chave: Mura. Consulta. Mineração. Conflitos. Autonomia. 


\begin{abstract}
This article aims to share the experience of holding the Assembly on Prior, Free and Informed Consultation with the Mura people. It originated within the justice process from the Action filed by the Federal Public Ministry in the face of complaints from the Mura people against activities of the silvinite exploration project called Projeto Potássio Autazes / Amazonas, without performing previously the PFIC. Such a discussion can serve to define previously the instruments, plans and mainly, the methodology used based on the participation, autonomy and social, political and cultural organization of the indigenous peoples. The Mura decided to elaborate the PCCLPI before the CPLI was held, defined the methodology for the elaboration of the protocol and expanded the number of Lands and villages that would be consulted by going beyond the limits of the municipality of Autazes, including regularized and unprotected lands.
\end{abstract}

Keywords: Mura. Consultation. Mining. Conflicts. Autonomy.

\title{
Resumen
}

Este artículo tiene por objetivo compartir la experiencia de realización de la Asamblea sobre la Consulta Previa, Libre e Informada junto al Pueblo Mura. Esta se originó dentro del proceso judicial a partir de una Acción, peticionada por el Ministerio Público Federal a causa de las denuncias del Pueblo Mura contra las actividades del megaproyecto de minerales para explotar silvinita, denominado Proyecto Potasio Autazes/Amazonas, sin haber realizado CPLI. Se busca demostrar la importancia de esta discusión que fue previa a la elaboración del Protocolo de Consulta y Consentimiento Libre, Previo e Informado. Esta discusión puede servir para que los pueblos indígenas definan sus instrumentos, planificaciones y principalmente la metodología utilizada fundamentalmente en la participación, autonomía y organización social, político y cultural de los pueblos indígenas. Los Mura decidieron elaborar el PCCPLI antes de realizar la CPLI, y así definieron la metodología para la elaboración del protocolo y ampliaron el número de Tierras y aldeas que serán consultadas extrapolando los límites del municipio de Autazes y sin importar si estas están demarcadas o no, ya que todas son Tierra Mura.

Palabras clave: Mura. Consulta. Minería. Conflictos. Autonomía.

\section{INTRODUÇÃO}

O Povo Mura denunciou a Empresa Potássio do Brasil junto ao MPF após obter a licença para fazer a prospecção do minério de Silvinita em Autazes em 2015 sem realizar a Consulta Prévia, Livre e Informada (CPLI) como determina a Convenção 169 da Organização Internacional do Trabalho (OIT). Culminou na Ação Civil Pública impetrada pelo Ministério Público Federal (processo número 19192-92.2016.4.01.3200) contra atividades do empReendimento minerário para a exploração de silvinita, denominado Projeto Potássio Autazes/Amazonas.

A Assembleia de discussão sobre o tema CPLI, naquele momento denominada de assembleia de pré consulta à Consulta Prévia, partiu da necessidade do povo Mura de entender o que é esse instrumento de consulta, os direitos e as legislações que a asseguram, conhecer e definir seus instrumentos e como queriam realizar esse processo. Já a Consulta Prévia propriamente dita, foi denominada de Consulta Prévia direta.

É importante não confundir essa assembleia, uma reunião de esclarecimento, com a CPLI. Essa discussão prévia em assembleia foi primordial para o Povo Mura, 
pois a elaboração de Protocolos de Consulta surgiu a partir da iniciativa dos próprios povos indígenas e das comunidades tradicionais, fundamentando isto no seu direito à autodeterminação. Destarte era necessário que existisse um momento de discussão e deliberação sobre os caminhos que como povo iriam tomar, haja vista que muitos povos indígenas têm suas formas próprias de tomada de decisão definidas por suas sociedades e que não são escritas.

Até aquele momento nenhum processo de CPLI, segundo os preceitos da Convenção 169 da OIT, havia sido feito no estado do Amazonas e tão pouco junto aos povos indígenas. E principalmente, porque essa reunião, ora denominada assembleia de pré consulta, foi prevista no processo judicial ante a Justiça Federal como cumprimento ao direito de autodeterminação do Povo Mura estabelecido na Convenção 169 da OIT e com o objetivo de esclarecer melhor os povos indígenas e comunidades tradicionais sobre esse instrumento para que assim pudessem iniciar e propor formas de planejamento e implementação de acordo com suas maneiras próprias de tomadas de decisão que se diferenciam de povo para povo, conforme sua organização social.

Desta forma, não há como implementar modelo para esse tipo de discussão pois iria contra a autonomia e a diversidade cultural, social e política desses, razão pela qual a Convenção foi criada. Destaca-se que denominamos naquele momento de consulta prévia direta, a consulta sem a necessidade de se elaborar tanto o protocolo quanto essa discussão prévia, ou seja, diretamente sem nenhum tipo de discussão anterior.

Conforme disposto na Convenção 169 da OIT, nas consultas prévias, os povos indígenas têm que ser ouvidos e suas decisões são vinculantes. Portanto, a metodologia de trabalho utilizada na assembleia de pré consulta à Consulta Prévia, foi participante utilizando a problematização, a pedagogia da pergunta e a técnica da escuta sensível. A mediação ocorreu sempre de forma coletiva, em grupos, para primeiro sabermos quais os conhecimentos que eles tinham sobre a questão, suas dúvidas, seus anseios e seus receios, sempre fundamentados na interculturalidade e nas formas próprias de organização social, política, cultural e autonomia do povo Mura assegurados pela legislação nacional e internacional.

Essa metodologia, gestão do conhecimento utilizada para discussão na assembleia consiste em reuniões ou oficinas participantes. Parte do conhecimento pré-existente dos sujeitos sociais envolvidos, valorizando suas tradições culturais que associadas ou não a outros conhecimentos e tecnologias sociais podem produzir um outro conhecimento coletivo, ou evidenciar um conhecimento já existente, porém, posto em esquecimento, visando a construção de projetos e propostas para intervir em seus contextos, com autonomia. Não pode haver indução ou imposição dos outros conhecimentos ocidentais ou não sobre os conhecimentos próprios. O outro conhecimento vem a medida da ne- 
cessidade e não pode se sobrepor ou inferiorizar aquele. Temos que deixar de lado o sentimento colonial de consumidores do saber e por meio da participação nas atividades e experiências próprias construírem ou reconstruírem seus conhecimentos, evidenciando suas epistemologias. (FARIA, 2018, p. 137)

Tem como objetivo respeitar e valorizar evidenciando as formas próprias de pensar, organizar, línguas, suas cosmologias e epistemologias, tratando-os como sujeitos e não objetos, para além de um pensamento abissal, parafraseando o prof. Boaventura de Souza Santos, de forma intercultural fundamentada na ecologia dos saberes. Pensar e utilizar metodologias participantes e coletivas respeitando as suas cosmologias é fundamental para a promoção da autonomia quando a diferença é posta de forma positiva e não como atraso ou inferioridade. (FARIA, 2018, p.134)

Todas as atividades sugeridas desde a proposta inicial foram discutidas e aprovadas em reuniões junto ao Povo Mura, cujos resultados respeitam sua autonomia e as legislações nacionais e internacionais que garantem a CPLI aos povos indígenas afetados por decisões legislativas ou administrativas. Portanto, a proposta metodológica usada nessa discussão prévia, não é modelo, mas uma maneira de discussão já praticada pelo Povo Mura em suas assembleias, reuniões nas aldeias e comunidades e bem como pelo Conselho Indígena Mura (CIM) quando vão discutir ou tomar algum tipo de decisão. Nesse caso, a interculturalidade é importante para esclarecer questões do mundo não indígena que contribuiriam para as tomadas de decisão futuras sobre o empreendimento da Potássio do Brasil em Autazes.

É importante esclarecer que nossa mediação com o apoio do Laboratório Dabukuri - Planejamento e Gestão do Território na Amazônia foi fundamental para garantir a autonomia do Povo Mura e a imparcialidade no processo e ainda a responsabilidade que a universidade e os cientistas assumem em desenvolver tais trabalhos técnicos. Ressaltamos ainda que a nossa participação só foi possível porque houve aceitação entre as partes envolvidas no processo, Justiça Federal, empresa e principalmente a Associação que representa o Povo Mura, o Conselho Indígena Mura CIM.

Para tanto a proposta metodológica deve estar em consonância com as epistemologias e cosmologias dos povos indígenas e a equipe de trabalho deve ter aceitação e gozar da confiança das partes envolvidas, principalmente dos povos indígenas.

\section{A DENÚNCIA: O DIREITO DO POVO MURA DE DER CONSULTADO}

No município de Autazes, no estado do Amazonas, foi descoberta a maior reserva de silvinita do Brasil. A silvinita é uma rocha sedimentar principalmente composta por dois sais, o cloreto de sódio e o cloreto de potássio, de onde pode ser extraído o potássio, 
que é um dos macronutrientes mais importantes para a nutrição vegetal e é empregado para a produção de fertilizantes químicos utilizados na agricultura convencional, sendo que $91 \%$ do potássio utilizado no brasil é importado. A dimensão das reservas minerais e a dependência externa do fornecimento foram fatores determinantes para que a empresa denominada "Potássio do Brasil” se interessasse pela exploração.

Em 2008 as pesquisas minerais foram autorizadas pelo Departamento Nacional de Produção Mineral (DNPM). A partir de 2010 a empresa passou a fazer os estudos de prospecção mineral e de viabilidade econômica para determinar a localização e extensão da reserva de silvinita e seu potencial econômico. As autorizações do DNPM incidiam sobre Terra Indígena Jauari, e a partir de 2013 às perfurações começaram a atingir diretamente esta terra indígena, que já estava em processo de demarcação e tinha os limites conhecidos através do relatório de identificação e delimitação.

Em maio daquele ano a empresa foi notificada pela FUNAI para que as operações parassem imediatamente, ato que foi ignorado pela empresa, que deu continuidade às atividades. Durante a pesquisa mineral, foram perfuradas áreas dentro desta terra indígena sem conhecimento e permissão do Povo Mura, chegando a afetar um cemitério sagrado da Aldeia Jawari. Concluídos esses estudos, em 2013 iniciaram-se os estudos de Impacto ambiental, referentes à fase da licença prévia do processo de licenciamento ambiental, tendo como base o termo de referência $\mathrm{N}^{\circ} 008 / 2014$ - GEPE, emitido pelo Instituto de Proteção Ambiental do Amazonas (IPAAM). O IPAAM demorou para encaminhar para FUNAI as informações técnicas necessárias para que pudesse elaborar o termo de referência sobre o Estudo do Componente Indígena (ECI) do processo de licenciamento, que foi emitido em maio de 2015. Mesmo sem a conclusão do ECI, em julho de 2015 os resultados dos estudos de impacto ambiental foram protocolados e a licença prévia $n^{0} 54 / 2015$ foi outorgada pelo IPAAM à Potássio do Brasil.

O Povo Mura não foi consultado para as autorizações de pesquisa e a realização das perfurações em seu território, que acabaram violando cemitérios sagrados e provocando sérios danos e indignação ao Povo Mura, tampouco foram consultados durante o processo de licenciamento. Esses fatos foram denunciados ao Ministério Público Federal, que expediu em julho de 2016 recomendação ao IPAAM para que cancelasse a licença prévia e à Potássio do Brasil que suspendesse as atividades de pesquisa na região até a realização da consulta em respeito à legislação existente.

Os pedidos não foram atendidos e o MPF levou o caso à justiça federal por meio da Ação Civil Pública nº19192-92.2016.4.01.3200 (ACP), solicitando liminarmente, em caráter de urgência: a suspensão liminar dos efeitos da licença prévia do empreendimento; suspensão dos efeitos das autorizações de pesquisa mineral; determinação de que a Potássio do Brasil se abstenha a realizar qualquer ato ou procedimento concer- 
nente à implementação do projeto e a realização de estudos complementares específicos para avaliar os impactos do empreendimento sobre as comunidades tradicionais ribeirinhas. Também solicitou, em caráter permanente: a nulidade da licença prévia do empreendimento, condenação da Potássio do Brasil a não fazer qualquer ato referente a implementação do projeto até a realização da Consulta Prévia Livre e Informada e a regularização do licenciamento ambiental pela esfera Federal (IBAMA) e não pelo órgão ambiental estadual (IPAAM).

Após realização de audiências de conciliação entre as partes (Representantes do Povo Mura, MPF e Potássio do Brasil) ficou definido que seriam realizadas assembleias para apresentar informações e esclarecer sobre o processo de CPLI e protocolos de consulta, com objetivo de que o Povo Mura debatesse a forma adequada de realização da consulta e o que iria se adequar a sua organização social. Esta etapa do processo de planejamento da CPLI foi denominada "Assembleia de Pré-Consulta" pois seria uma etapa de preparação onde os Mura teriam que decidir se seu processo de decisão seria estabelecido por um Protocolo de Consulta (o qual representaria a necessidade de construção deste protocolo) ou se realizariam o processo de consulta sobre a exploração de silvinita sem protocolo. Também ficou definido que as despesas seriam custeadas pela empresa Potássio do Brasil e para a condução das assembleias foi nomeada a prof. Dra. Ivani Ferreira de Faria, da Universidade Federal do Amazonas e indicada a participação do antropólogo Bruno Caporrino como observador e facilitador do diálogo com o Povo Mura pelo MPF.

\section{O EMPREENDIMENTO MINERÁRIO PARA EXPLORAÇÃO DE SILVINI- TA - PROJETO POTÁSSIO AUTAZES/AMAZONAS}

O Projeto Autazes, empreendimento em questão, da empresa "Potássio do Brasil" contempla uma unidade para lavrar e beneficiar em superfície minério proveniente de camadas de silvinita - composta principalmente por sais de cloreto de sódio $(\mathrm{NaCl})$ e cloreto de potássio (KCL) - tendo o objetivo de extrair, purificar e comercializar grânulos de KCL.

A Jazida de silvinita está localizada no município de Autazes/AM, estando situada a cerca de $130 \mathrm{Km}$ de Manaus, possui $13 \mathrm{~km}$ de comprimento e $10 \mathrm{~km}$ de largura, se sobrepõe à Terra Indígena Jauari e outros territórios tradicionalmente ocupados pelos Mura, que ainda necessitam de providências de demarcação. É possível observar (Figura 1) a localização planejada para a infraestrutura principal do empreendimento, bem como a localização da Jazida e sua sobreposição com a TI Jauari. A jazida está localizada em profundidades de 700 a 900 m abaixo do solo, com espessura lavrável 
que varia de 1 a 3,5m e possui capacidade de produção anual de 2.440 .000 t de KCL granulado a uma pureza de $95 \%$.

A documentação enviada pela empresa no processo de licenciamento prevê que a exploração da silvinita será realizada pelo método de câmaras e pilares, a mina será dividida em eixos de desenvolvimento principal e câmaras de exploração. A retirada da silvinita para o beneficiamento em superfície será realizada por meio de 2 poços tipo shaft e galerias subterrâneas que serão abertas ao longo da exploração e conforme forem deixando de ser utilizadas serão preenchidas por rejeitos (material extraído do subsolo não utilizado comercialmente).

A planta de beneficiamento prevê capacidade para beneficiar 8.500 .000 t de silvinita por ano. De forma simplificada, a silvinita será extraída ao longo das câmaras subterrâneas e retirada por sistema de transporte vertical e armazenada em dois silos. Destes silos poderá ser encaminhada à uma pilha de estocagem, ou diretamente para as instalações de britagem para diminuir o tamanho dos fragmentos de silvinita para poderem seguir para a estação de lixiviação a quente.

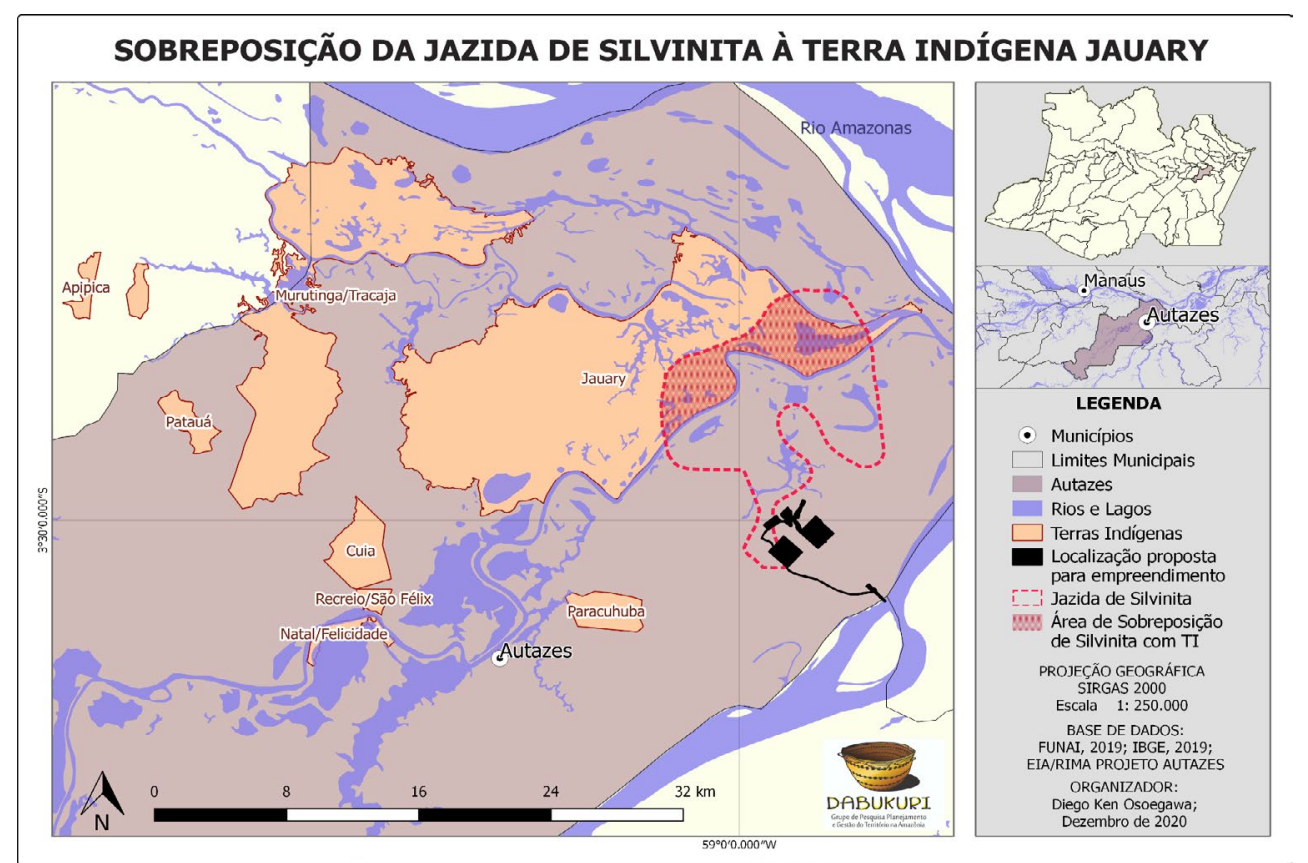

Figura 1 - Localização do empreendimento no município de Autazes.

Fonte: OSOEGAWA, Laboratório Dabukuri/UFAM. Manaus, dezembro de 2020.

Nesta estação uma salmoura é aquecida à determinada temperatura, de forma a fazer com que o cloreto de potássio se dissolva e o cloreto de sódio se mantenha em forma sólida. Em seguida ocorre separação do KCL que não foi completamente dissolvido (que retorna ao processo de lixiviação a quente). Por fim, ocorre o resfriamento da solução para a cristalização do KCL purificado, remoção da umidade e compactação. 
O processamento prevê a produção de grande quantidade de rejeitos, cerca de 4.740.000 t/ano, que serão compostos principalmente de cloreto de sódio e cloreto de magnésio. O projeto indica que parte desse rejeito pode ser utilizada para preenchimento das cavidades lavradas no subsolo e que parte necessitará ser disposta em duas grandes áreas de gerenciamento de rejeitos, cada uma com uma pilha de estocagem de $1,2 \mathrm{~km} \mathrm{x} \mathrm{1,2} \mathrm{km} \mathrm{de} \mathrm{extensão,} \mathrm{chegando} \mathrm{à} \mathrm{altura} \mathrm{de} 20 \mathrm{~m}$, com volume estimado de 24.000.000 toneladas de rejeitos cada.

O planejamento para este resíduo é deixar que ocorra o processo natural de lixiviação, produzindo uma salmoura altamente concentrada em sais, para que esta seja injetada na porção basal da formação Alter do Chão (localizada entre 310 a 400m de profundidade). Haverá estrutura de drenagem, estocagem e injeção de salmoura, composto por 14 poços localizados próximos às pilhas de rejeito, que introduzirão esse resíduo altamente salino no subsolo ao longo da fase de exploração do empreendimento e por mais 30 anos após o fechamento do empreendimento. Além dos resíduos solúveis estima-se que de 10.000.000 a 12.000.000 $\mathrm{m}^{3}$ de resíduos serão insolúveis, compostos de materiais argilosos, que serão dispostos em células e envolvidos por geomantas.

A infraestrutura do empreendimento também contará com a construção de porto fluvial na vila de Urucurituba, no rio Madeira, para o escoamento da produção. Anexo ao porto será construído galpão de armazenamento do produto e quatro cais flutuantes, capazes de se acoplarem. A infraestrutura foi planejada para comportar ao menos 20 barcaças de $2.000 \mathrm{t}$ cada (totalizando $40.000 \mathrm{t}$ ) e ancoradouro para barcaça com óleo diesel. O projeto ainda prevê que para interligar o porto à planta de beneficiamento uma estrada padrão classe II do DNIT, a proposta para a construção dessa estrada é a ampliação e asfaltamento de um caminho vicinal não pavimentado já existente na região.

O projeto indica que na fase de implantação do empreendimento serão necessários 1200 funcionários e 1400 durante a fase de exploração. Diante dessas informações fica evidente o grande porte do empreendimento sendo possível ter a noção da dimensão dos volumes que serão extraídos, produzidos e transportados, bem como as possíveis modificações no fluxo de embarcações, e na dinâmica migratória para ocupar os postos de trabalho.

\section{A REIVINDICAÇÃO DO DIREITO DE CONSULTA PRÉVIA, LIVRE E IN- FORMADA E AUTODETERMINAÇÃO DO POVO MURA}

O Povo Mura começou a reivindicar o direito de CPLI quando foram desenvolvidas as oficinas apoiadas pelo Conselho Indigenista Missionário (CIMI), motivadas 
pela indignação que suscitou a perfuração de um antigo cemitério localizado na terra indígena Jauary. A partir deste evento, o povo Mura apresentou denúncias ao MPF, que em 2015 apresentou ACP, solicitando à Justiça Federal a paralisação de qualquer atividade da empresa Potássio do Brasil, sem a devida CPLI sobre o empreendimento que já contava com a licença prévia.

O direito de CPLI pode ser encontrado especificamente em dois corpos normativos internacionais, a Convenção 169 da Organização Internacional do Trabalho (OIT) e a Declaração das Nações Unidas sobre os Direitos dos Povos Indígenas, e este se fundamenta em vários princípios do direito que tratam sobre direitos humanos. Nos últimos anos houve um aumento nos registros das reivindicações dos povos indígenas, dos quilombolas e das comunidades tradicionais por projetos de desenvolvimento, exploratórios de recursos naturais que cada vez mais vão pressionando os territórios de uso tradicional.

A Convenção 169 da OIT foi emitida em 1989, e ratificada pelo Brasil em 2002, sendo está de caráter vinculante para os Estados que a ratificaram. A questão da obrigatoriedade da realização de processos de CPLI já deveria ser uma questão superada. Quando o Brasil ratificou a Convenção 169 da OIT, se obrigou a cumprir com todos os preceitos legais contidos nela, portanto, quando no Brasil existe uma medida administrativa ou legislativa que irá afetar aos povos indígenas, comunidades tradicionais e quilombolas, o estado brasileiro está obrigado a realizar processos de CPLI respeitando a diversidade cultural destes grupos sociais.

Existe ampla literatura que traz diversas definições do que deve ser considerada a CPLI, suas características e princípios. Por sua parte, encontramos no artigo 6 da Convenção 169 da OIT, que:

(...) Ao aplicar as disposições da presente Convenção, os governos deverão: a) consultar os povos interessados, mediante procedimentos apropriados e, particularmente, através de suas instituições representativas, cada vez que sejam previstas medidas legislativas ou administrativas suscetíveis de afetá-los diretamente (...). (OIT, 1989)

Anaya (2013, p. 20) afirma sobre a CPLI que este corresponde a um diálogo de boa-fé, onde ambas partes cheguem a um consenso:

A consulta consiste num diálogo de boa-fé, livre de pressões ou manipulações, pela qual as partes tentam e cooperam para chegar a uma decisão em consenso. O dever dos Estados de consulta aos povos indígenas neste sentido procede quando seus direitos da propriedade sobre suas terras podem ser afetados. Também aplica quando outros direitos podem ser afetados, como seu direito à cultura e religião, por exemplo, quando uma decisão pode afetar sítios sagrados, ou o direito dos povos indígenas de estabelecer suas próprias prioridades para seu desenvolvimento. 
Já na Declaração das Nações Unidas sobre os Direitos dos Povos Indígenas nos seus artigos 10 e 19, este direito é muito mais desenvolvido no sentido de afirmar que é necessário obter o Consentimento Livre, Prévio e Informado, quando se trate que os povos indígenas sejam removidos ou obrigados a sair dos seus territórios:

Artigo 10: Os povos indígenas não serão removidos à força de suas terras ou territórios. Nenhum traslado se realizará sem o consentimento livre, prévio e informado dos povos indígenas interessados e sem um acordo prévio sobre uma indenização justa e equitativa e, sempre que possível, com a opção do regresso (...)

Artigo 19: Os Estados consultarão e cooperarão de boa-fé com os povos indígenas interessados, por meio de suas instituições representativas, a fim de obter seu consentimento livre, prévio e informado antes de adotar e aplicar medidas legislativas e administrativas que os afetem. (ONU, 2017)

A CPLI tem-se caracterizado por reunir em si mesma uma série de elementos que permitem a participação dos povos indígenas na tomada de decisões que lhes afetem diretamente, respeitando para isto suas formas de se organizar e entender o mundo.

Assim como têm afirmado o Comitê para a Eliminação da Discriminação Racial e o Comitê de Direitos Humanos da ONU, a CPLI tem relação com os princípios da não discriminação e integridade cultural, e os governos estão obrigados a garantir aos povos indígenas o disfrute dos direitos em condições de igualdade em relação a sua participação no âmbito público, assim como também, estão obrigados a não tomar uma decisão sem o consentimento informado destes, já que esta norma tem seu fundamento nos princípios do autogoverno e autodeterminação. (ANAYA, 2005, p. 237)

A consulta está baseada no princípio de autogoverno e no princípio de participação, ambos permitem a efetividade da autodeterminação. Por meio da CPLI, às comunidades indígenas além de encontrar efetivado o aspecto político do seu direito de autodeterminação, podem participar no panorama político. Este panorama permite a reivindicação das exigências pelo respeito dos direitos dos povos indígenas, assim como também a manifestação da sua cultura, a partilha dos seus conhecimentos tradicionais, e a existência de uma diversidade cultural esquecida por vários séculos.

Como podemos observar na Convenção 169 da OIT, não se estabelece especificamente a elaboração dos protocolos de Consulta e Consentimento Prévio, Livre e Informado. Estes têm surgido nos distintos países, como forma autônoma que os povos indígenas, comunidades tradicionais e quilombolas encontraram para defender $o$ respeito às suas próprias formas de organização social e tomada de decisão. 
Neste sentido a juíza que estava conhecendo a ACP e mediando as audiências de conciliação entre MPF e a empresa Potássio do Brasil, Ltda., em cumprimento ao direito de autodeterminação dos povos indígenas, determinou que seria o Povo Mura quem deveria decidir a forma em que estes queriam ser consultados, seus tempos e os instrumentos adequados para efetivar este importante direito.

Para o Povo Mura a reivindicação desse direito desde o início, foi uma luta constante contra os preconceitos e as incertezas. Durante os estudos que foram realizados pela empresa Potássio do Brasil, se afirmava que não existiam povos indígenas na região. O primeiro contato com as lideranças Mura, esteve marcado pelos esclarecimentos das principais características do direito da CPLI. Ao falar sobre este direito é impossível não reconhecer que se trata de um direito relativamente novo, em comparação com outros direitos (Terra, saúde e educação por exemplo), este ainda se encontra em constante evolução.

Verificamos que existiam conceitos como consultas públicas, audiências públicas e planos de Consulta Prévia, que eram confundidos uns com os outros, quanto a suas finalidades e seus objetivos. Assim, ficou evidente que existia uma confusão quanto aos instrumentos (a possibilidade de criar seu próprio Protocolo de Consulta Prévia, Livre e Informada) que deveriam ser aplicados no caso específico, e para o qual seria necessário ter uma abordagem intercultural e um mesmo entendimento enquanto a importância que estas características fossem respeitadas.

Para isto foi fundamental ter muito claras as características do direito à CPLI que durante a assembleia também foram trabalhadas utilizando vários procedimentos metodológicos que nos permitiram dialogar e pôr em prática conforme o contexto que o Povo Mura estava vivenciando. As características mais importantes a tratar foram:

A consulta é prévia: partimos do princípio que o direito à CPLI determina que esta deve ser prévia já que deve se realizar antes de qualquer decisão ou atividade que lhes afete aos povos indígenas. O objetivo de determinar que a CPLI deve ser prévia, é a necessidade de contar com a participação da comunidade em todo o processo da medida, pois não se trata de uma pergunta que deve ser respondida "sim" ou "não", mas deve corresponder a um verdadeiro diálogo intercultural, horizontal, e para isto é fundamental que a discussão anteceda a decisão.

A Convenção 169 da OIT (SILVA, 2008, p. 58), contínua estabelecendo no artigo 16 , numeral 2, que a consulta deve ser prévia a qualquer ato administrativo, devido aos possíveis prejuízos que possam acontecer no território indígena. Se a empresa Potássio do Brasil bem como o IPAAM, houvesse respeitado desde o início de suas atividades o direito de CPLI do Povo Mura, por exemplo, possivelmente não teria sido perfurado o cemitério na Terra Indígena Jauary, pois existia um entendimento da empresa sobre o território, a partir do olhar do Povo Mura. 
Mesmo que a consulta seja prévia, permite que exista tempo suficiente para que as comunidades se informem e preparem para participar no processo de decisão da medida. Permite determinar desde o início "as regras do jogo", desde seu planejamento, e não quando já se conta com uma licença prévia. (MAZARIEGOS, 2014)

Então, não é suficiente afirmar que a consulta tem que ser prévia à decisão final, tem que ser prévia a qualquer atividade que tenha por objetivo estabelecer uma medida administrativa ou legislativa, tomando em consideração que esta impactará de forma negativa ou positiva, a uma ou várias comunidades.

Neste sentido, constatamos que a participação do Povo Mura no processo de autorização na exploração de silvinita, desde o início, se viu vulnerada. A licença de exploração mineral outorgada pelo IPAAM foi outorgada sem previamente ter ouvido as comunidades.

A consulta é livre: a liberdade da CPLI, determina que esta deva se dar sem pressões ou coações por parte das autoridades do estado ou das empresas exploradoras dos recursos, nem por qualquer outra entidade ou pessoa que tenha interesse ou não na exploração. Já que se pretende conseguir o consentimento da comunidade, e tendo em consideração que o direito a CPLI é um ato jurídico, e todo ato jurídico produz efeitos quando pouse as caraterísticas de discernimento, intenção e liberdade, para que a decisão da comunidade seja legítima, não se pode permitir nenhum ato que viole a manifestação da vontade da comunidade.

Considera-se que a consulta tem que ser livre, segundo o direito à informação, que os interessados conheçam a detalhe as consequências que a medida trará, e segundo isto possam emitir ou não o seu consentimento. Assim mesmo o processo da consulta tem que ser uma negociação horizontal entre as comunidades e as empresas, respeitando os métodos de tomada de decisões tradicionais, os quais são aceitos, reconhecidos e legitimados pela comunidade. (MAZARIEGOS, 2014, p.430)

A consulta é informada: determina-se que a consulta tem que ser informada, já que, unida a caraterística da liberdade da consulta, é impossível conseguir o consentimento da comunidade, sem outorgar todas as informações sobre os benefícios, custos, prejuízos e riscos, que trará a medida.

A consulta informada significa ter de realizar alguns estudos precisos para informar as comunidades todo o panorama do que acontecerá com a medida. Isto não tinha acontecido no caso do Povo Mura, pois como pudemos constatar existiam muitas confusões quanto ao direito de CPLI e sobre os impactos que a exploração de silvinita traria para seus territórios.

A consulta tem que ser realizada de boa fé: a caraterística que a consulta tem que ser realizada de boa-fé encontra-se regulamentado no artigo 6 da Convenção 169 da OIT no numeral 2, o qual dita literalmente que: 
(...) 2. As consultas realizadas na aplicação desta Convenção deverão ser efetuadas com boa-fé e de maneira apropriada às circunstâncias, com o objetivo de se chegar a um acordo e conseguir o consentimento acerca das medidas propostas. (OIT, 1989)

Esta se refere que durante o processo da consulta a negociação entre comunidades, empresas e Estado, tem que se guiar pela boa fé dos sujeitos; quer dizer que o atuar destes tem que estar livre de pressões, evitando qualquer ato que possa provocar que a manifestação da vontade da comunidade, seja afetada.

$\mathrm{Na}$ Assembleia do Povo Mura foram levantadas várias questões que não estavam esclarecidas, e que serão tratadas mais na frente. Num primeiro momento achamos necessário tratar algumas diferenças para ter um melhor entendimento sobre a CPLI e outros instrumentos de participação cidadã como as audiências públicas (Quadro 1).

Quadro 1 - Características da Consulta Prévia Livre e Informada e Audiência Pública

\begin{tabular}{|l|l|}
\multicolumn{2}{|c|}{ Consulta Prévia Livre e Informada } \\
$\begin{array}{l}\text { É um conjunto de reuniões que têm por objetivo } \\
\text { informar sobre um determinado projeto, para que } \\
\text { um povo possa tomar uma decisão, a qual terá que } \\
\text { ser aceita pelo governo. }\end{array}$ & $\begin{array}{l}\text { É uma reunião pública entre vários setores da } \\
\text { sociedade com autoridades públicas. }\end{array}$ \\
\hline $\begin{array}{l}\text { Não se trata de uma reunião, e sim de todo um pro- } \\
\text { cesso que tem por objetivo obter o consentimento } \\
\text { de um povo indígena e comunidades tradicionais. }\end{array}$ & $\begin{array}{l}\text { É uma reunião que versa sobre assuntos de } \\
\text { interesse de várias pessoas da sociedade. É } \\
\text { dizer que pode ser celebrada por qualquer } \\
\text { assunto de interesse da coletividade. }\end{array}$ \\
\hline $\begin{array}{l}\text { A Consulta Prévia tem por objetivo chegar a um } \\
\text { consenso entre o governo e um povo determinado } \\
\text { que será afetado por alguma decisão, respeitando o } \\
\text { direito de autodeterminação do povo. }\end{array}$ & $\begin{array}{l}\text { Na Audiência pública as autoridades do Estado } \\
\text { não pretendem obter o consenso dos setores } \\
\text { da sociedade desenvolvida, já que a decisão fi- } \\
\text { nal estará no poder da autoridade pública. }\end{array}$ \\
\hline $\begin{array}{l}\text { Durante todo o processo é necessário que existam } \\
\text { especialistas que informem ao povo sobre a medi- } \\
\text { da administrativa ou legislativa que lhes afetará. }\end{array}$ & $\begin{array}{l}\text { É uma audiência para dar participação e } \\
\text { promover o debate entre os cidadãos e as } \\
\text { autoridades públicas nas decisões de um } \\
\text { determinado assunto. }\end{array}$ \\
\hline $\begin{array}{l}\text { Corresponde a um direito fundamental dos povos } \\
\text { indígenas e comunidades tradicionais. }\end{array}$ & $\begin{array}{l}\text { Corresponde a um instrumento de participa- } \\
\text { ção da sociedade que permite um debate de- } \\
\text { mocrático, mas não de decisão. }\end{array}$ \\
\hline
\end{tabular}

Fonte: FARIA, CASTRO, 2018.

Foi esclarecido durante a Assembleia que a legislação não estabelece tempos ou momentos adequados para elaborar os Protocolos de Consulta e Consentimento Prévio, Livre e Informado, que esta tem sido uma prática que os povos indígenas, quilombolas e comunidades tradicionais têm exercido e que fundamentam no seu direito de autodeterminação nas caraterísticas da CPLI, que determina que devem ser processos culturalmente adequados, e que será o grupo social afetado quem decidirá. 
Seguindo isto, o Povo Mura tinha duas possibilidades: elaborar seu Protocolo de Consulta e Consentimento Prévio, Livre e Informado (CCPLI) ou ser consultados de uma vez, sem elaborar seu protocolo, sobre a exploração de silvinita. Para isto foi utilizado o termo de Consulta Prévia (Direta) o qual em conversações posteriores achamos o termo não adequado, mas colocamos no presente artigo pois foi o que utilizamos durante a assembleia e no relatório final.

Com a Consulta Prévia Direta não estamos afirmando que existem Consultas Prévias que podem ser mediadas ou que seriam realizadas por intermédio de outros atores que não sejam os povos sujeitos deste direito. Consulta Prévia Direta foi o termo que encontramos que podia expressar o fato do Povo Mura ser consultado de uma vez sobre a exploração de silvinita, sem realizar o protocolo de consulta, pois tínhamos que apresentar isto como uma possibilidade.

Embora apresentemos estas possibilidades explicamos como a elaboração dos Protocolos de CCPLI (Quadro 2), não somente representa uma preparação prévia para um processo tão complicado como são os processos de CPLI, mas também, como aconteceu no caso do Povo Mura, pode representar um processo que permite a união e uma reorganização social. Este permite deixar para traz qualquer tipo de diferenças, conflitos e desentendimentos que possam existir em qualquer grupo social, para colocar em primeiro lugar as reivindicações e o bem-estar da coletividade.

Para melhor entendimento dos participantes descrevemos as diferenças mais importantes entre cada instituto (Quadro 2):

Quadro 2 - Características do Protocolo da Consulta e Plano de Consulta Prévia

\begin{tabular}{|c|c|}
\hline Protocolo da Consulta & Plano de Consulta Prévia \\
\hline $\begin{array}{l}\text { Documento que define como um povo indígena } \\
\text { quer ser consultado pelo Estado sobre qualquer } \\
\text { empreendimento em suas Terras ou comunidades. }\end{array}$ & $\begin{array}{l}\text { Documento que orienta a realização de um } \\
\text { processo de consulta prévia específico, sendo } \\
\text { construído e acordado pelo consenso entre } \\
\text { seus participantes. }\end{array}$ \\
\hline $\begin{array}{l}\text { É elaborado de forma geral e pode ser aplicado a } \\
\text { qualquer empreendimento, decisão administrativa } \\
\text { ou decisão legislativa que afete o território ou } \\
\text { direitos indígenas do povo envolvido. }\end{array}$ & $\begin{array}{l}\text { É específico, elaborado para o processo de } \\
\text { consulta de um determinado empreendimento, } \\
\text { decisão administrativa ou legislativa que afete } \\
\text { um povo indígena. }\end{array}$ \\
\hline $\begin{array}{l}\text { São construídos exclusivamente de acordo com a } \\
\text { autodeterminação do povo indígena, que podem } \\
\text { convidar e engajar instituições que consideram re- } \\
\text { levantes e que possam contribuir com o processo. }\end{array}$ & $\begin{array}{l}\text { O Plano de Consulta é construído especifi- } \\
\text { camente para colocar no papel como será } \\
\text { realizado um processo de CPLI sobre um em- } \\
\text { preendimento ou sobre uma decisão que será } \\
\text { consultada aos povos indígenas, quilombolas } \\
\text { ou comunidades tradicionais. }\end{array}$ \\
\hline $\begin{array}{l}\text { Tem caráter de orientação geral, indicando de for- } \\
\text { ma geral as premissas e diretrizes a serem observa- } \\
\text { das num processo de consulta, etapas e atividades } \\
\text { gerais a serem realizadas e definidas caso a caso. }\end{array}$ & $\begin{array}{l}\text { Tem caráter operacional, indicando o crono- } \\
\text { grama com detalhamento de atividades espe- } \\
\text { cíficas, agendamento de datas e os recursos } \\
\text { necessários para a realização das mesmas. }\end{array}$ \\
\hline
\end{tabular}


(Continuação)

Protocolo da Consulta

O Protocolo de Consulta não possui objeto específico, mas serve de orientação geral para ser definida/ aplicada caso a caso.

O Protocolo de Consulta nasceu para explicar aos terceiros como é que os povos indígenas, quilombolas ou comunidades tradicionais devem ser consultados. Estes refletem uma identidade do grupo social, assim como a organização social, a forma de tomada de decisão já existente.
Plano de Consulta Prévia

O Plano de Consulta deve necessariamente ser aplicado a um objeto específico de consulta (decisão administrativa ou legislativa).

É um instrumento muito mais operacional e impessoal. Tem por objetivo detalhar como será realizado o processo de CPLI. Não procura reforçar a identidade de um grupo social.

Fonte: FARIA, CASTRO, 2018.

\section{CONSTRUINDO O PROCESSO DA ASSEMBLEIA DA PRÉ CONSULTA À CONSULTA PRÉVIA}

O processo de discussão da assembleia da Pré Consulta à Consulta Prévia teve início no dia 05 de dezembro de 2017 com a apresentação da Proposta pela Empresa Potássio do Brasil a Juíza Federal, Dra. Jaiza Pinto Fraxe, da $1^{\mathrm{a}}$ Vara do Tribunal Regional Federal da Primeira Região, Seção Judiciária do Estado do Amazonas, no âmbito da ACP movida pelo MPF.

Durante a reunião supracitada lideranças Mura foram consultadas sobre a proposta de realização da assembleia da Pré Consulta à CPLI, quando foi apresentado também o nosso nome para mediar as atividades, aceita de antemão pelas partes envolvidas. Mesmo com a aprovação, o CIM solicitou um prazo para discussão da mesma com as lideranças representantes das comunidades/aldeias. Em decorrência dessa solicitação, a Juíza acatou a proposta do CIM com o estabelecimento do prazo até 08 de janeiro de 2018 para que apresentassem sugestões e/ou alterações à proposta da Assembleia da Pré Consulta à Consulta Prévia.

Vale ressaltar que a nossa aceitação em participar desse trabalho ocorreu mediante uma consulta anterior à algumas lideranças e outros parceiros indigenistas e também à proposta apresentada, que não tinha nenhuma atividade fechada a não ser a primeira reunião de articulação e planejamento da assembleia da pré consulta. Nessa primeira reunião, seriam estabelecidas pelo Povo Mura todas as datas, regras, condições, conteúdo, pessoas que seriam convidadas e autorizadas a participar, ou seja, os Mura que deram o rumo, orientaram e encaminharam todos as atividades e procedimentos para a realização da assembleia como já faziam anteriormente.

No entanto, o CIM teve dificuldades para organizar a reunião para discussão da proposta em tempo hábil, devido a questões orçamentárias e de logística. Em contato com as lideranças do CIM, sugerimos que a reunião de articulação/planejamento da Pré consulta com as lideranças da associação e das comunidades/aldeias, que consta da 
proposta apresentada no dia 17 de dezembro de 2017, poderia ser antecipada caso eles concordassem, pois, os custos seriam arcados pela empresa haja vista que já havia um recurso depositado em juízo. Desta forma aproveitaram o momento para discutirem a proposta e definirem o que seria necessário à sua realização, uma vez que já havia sido aprovada como supracitado. Após concordância do CIM, levamos a sugestão a Potássio do Brasil que acenou positivamente apresentando-a a Juíza Dra. Jaiza Pinto Fraxe.

\subsection{Reunião de planejamento dia 05 de janeiro de 2018}

Após autorização pela Juíza em questão, em concordância com o MPF e o CIM, foi realizada a reunião de planejamento da Pré Consulta no dia 05 de janeiro de 2018 na sede da Secretaria Municipal de Educação de Autazes (SEMED), em Autazes.

A reunião contou com a participação de aproximadamente 115 indígenas Mura representantes de 24 aldeias pertencentes aos municípios de Autazes, Careiro da Várzea, Careiro Castanho e Manaquiri, das organizações: Organização dos professores indígenas Mura (OPIM); Associação dos Produtores Indígenas Mura de Autazes (OPIMA); Organização dos Mulheres Indígenas Mura (OMIM); Organização dos Estudantes Mura (AEIM); Organização dos Agentes de Saúde Indígenas Mura (OASIM) e demais instituições Fundação Nacional do Índio/FUNAI na pessoa do coordenador Regional Sr. Edivaldo Oliveira; Conselho Indigenista Missionário (CIMI), Ivani Faria, membros do Laboratório Dabukuri - UFAM (Diego Ken Osoegawa, Cirlene Batista, Guilherme Vilagelim) e o Antropólogo Bruno Caporrino representante enviado pelo MPF.

A reunião teve como objetivo promover uma discussão com o povo Mura, habitantes das TIs dos municípios de Autazes e Careiro da Várzea para analisarem a proposta da assembleia da Pré Consulta à Consulta Prévia apresentada e apresentarem sugestões e alterações no planejamento conforme suas formas de tomada de decisão, tempo e disponibilidade que foi mediada por nós e coordenada pela diretoria do CIM.

A reunião iniciou-se às $9 \mathrm{~h}$ com discussão e aprovação da pauta e conteúdos previamente acordados com a diretoria do CIM, sendo que os itens a, b e c foram discutidos pela manhã, e o item d, a tarde em grupos com sistematização dos resultados às $17 \mathrm{~h}$, que foi detalhado em relatório enviado às partes.

Os itens da pauta foram: a) Apresentação das lideranças presentes coordenada pela diretoria do CIM; b) Informes sobre o que é Consulta Prévia e seus instrumentos, protocolo de consulta e consulta direta; c) Apresentação da proposta da Pré Consulta à Consulta Prévia (assembleia) mediada por nós com apoio dos diretores do CIM; d) Discussão e definição (local, data, participantes, número de pessoas por comunidade, quais comunidades, horário e equipe de organização). 
Como resultado foi deliberado o seguinte:

a) a aldeia de Murutinga foi escolhida como local da assembleia devido a facilidade de deslocamento entre as aldeias e por ter infraestrutura adequada para comportar a assembleia;

b) definiram que a assembleia teria duração de 3 dias e realizada de 20 a 22 de fevereiro de 2018 mais dois dias de deslocamento, totalizando 5 dias (ida 19 de fevereiro e retorno 23 de fevereiro). Esse período e tempo de duração foi definido por eles porque é o tempo que costumam realizar reuniões e o mês que não conflitaria com outras atividades já agendadas nas suas aldeias. A proposta da equipe foi de 4 dias, porém, acharam muito tempo, quase uma semana levando-se em consideração o deslocamento de ida e volta de suas aldeias para Murutinga e que não poderiam ficar tanto tempo fora de deixando suas atividades e trabalhos;

c) propuseram 05 pessoas por comunidade entre professores, tuxauas, conselheiros, agentes de saúde indígena, pais, jovens e mulheres definidos pelas respectivas aldeias. Esse quantitativo também foi proposto por eles devido a outras reuniões já ocorridas com essa configuração;

d) Conteúdo a ser abordado seria sobre a Convenção 169, o protocolo de consulta prévia, o empreendimento e seus impactos tendo em vista que muitos ainda não conheciam e não sabiam bem do que se tratava. Só havia ocorrido reuniões da Estudo de Componente Indígena (ECI) em 4 aldeias e outras com discussão preliminar para elaboração do protocolo de consulta, a cargo do antropólogo Bruno Caporrino, sob orientação do MPF;

e) também ficou decidido que as comunidades/aldeias que participariam seriam as localizadas nos municípios de Autazes, Careiro da Várzea, Careiro Castanho e Manaquiri e as organizações OPIM, OMIM, OEIM, OPIMA, OASIM, FUNAI, MPF, CIMI;

f) esperavam cerca de 250 Mura, número usado para elaborar o orçamento e organizar a logística em Murutinga, e por fim,

g) que a mediação e organização seriam feitas pelo CIM e Profa. Ivani Faria

\section{A programação aprovada}

$1^{\circ}$ dia - Apresentação dos participantes e das instituições; Discussão Sobre o que trata a Convenção 169 da OIT? Qual a importância da Consulta Prévia aos Povos Indígenas? Quais os instrumentos e procedimentos usados para a Consulta Prévia? Quais povos foram consultados? Como foi o processo? Quais resultados? e discussões em grupos, esclarecimentos de dúvidas e debate.

$2^{\circ}$ dia - Discussão sobre o empreendimento e seus impactos (componente Indígena); discussões em grupos, esclarecimentos de dúvidas e debate. 
$3^{\circ}$ dia - Discussão em grupo: Qual o instrumento a ser utilizado no processo de Consulta Prévia do empreendimento de mineração de Cloreto de Potássio $(\mathrm{KCl})$ a partir do processamento do mineral Silvinita? e PORQUE? O que fariam? Como seria feito? Quem poderia participar? Quais aldeias? Número de pessoas? Quais seriam os parceiros convidados? Apresentação das discussões pelos grupos, esclarecimentos de dúvidas, debate com definição do instrumento de Consulta Prévia, protocolo de consulta, metodologia e avaliação da assembleia.

Como acordado, a Potássio do Brasil não participou da reunião e arcou com as despesas com logística no que se refere ao deslocamento de todos os participantes com a cessão de combustível, alimentação (café da manhã, almoço e lanche da tarde) e compra de material de expediente.

Não houve nenhuma interferência da Potássio do Brasil e de seus funcionários do escritório instalado na sede de Autazes na reunião, pois a organização da logística e interlocução foi realizada pela equipe do Laboratório Dabukuri/UFAM. E ao contrário do que possa ser interpretado, o custeio da assembleia foi determinado pela Justiça Federal e já estava depositado em juízo.

\subsection{Assembleia da Pré Consulta à Consulta Prévia de 20 A 22 de Fevereiro de 2018}

A assembleia teve por objetivo esclarecer sobre o processo de CPLI e debater sobre a temática definindo os instrumentos e metodologia que seriam implementados neste processo.

A chegada da maioria das delegações ocorreu no dia 19 de fevereiro de 2018 na aldeia de Murutinga com recepção do Tuxaua local e o retorno de parte dos participantes na noite do dia 22 e os demais na manhã do dia 23 de fevereiro de 2018.

Participaram da assembleia cerca de 220 Mura de 37 aldeias localizadas nos municípios de Autazes e Careiro da Várzea (Figura 2). As aldeias Mura dos municípios de Manaquiri e Careiro Castanho não participaram por falha na comunicação entre eles. A responsabilidade da comunicação ficou a cargo das lideranças. As aldeias Remanso, Ajuricaba, Igarapé Açu, Padre e Muratuba estavam programadas na reunião de organização da logística e foram convidadas, mas não compareceram. $O$ representante da FUNAI, somente compareceu no dia 22 de fevereiro de 2018. 


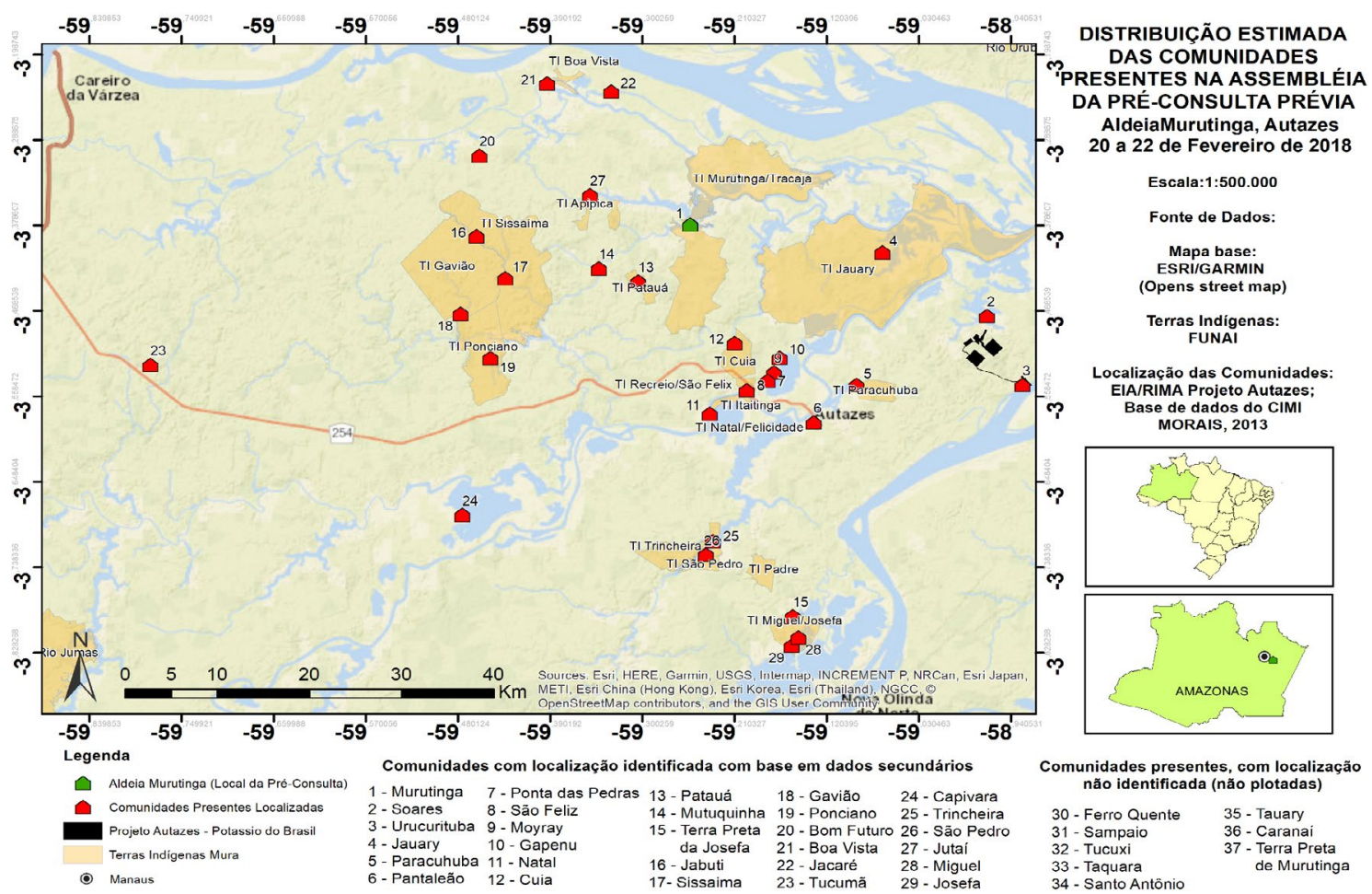

Figura 2 -Aldeias presentes na assembleia da Pré Consulta à Consulta Prévia em Murutinga/AM.

Fonte: OSOEGAWA, Laboratório Dabukuri/UFAM. Manaus, fevereiro de 2018.

Aldeias presentes: Murutinga, Josefa, São Pedro, Ferro Quente, Capivara, Moyray, Natal, Trincheira, Miguel, Sampaio, Terra Preta da Josefa, Jabuti, Cuia, Soares, Urucurituba, Tucuxi, Pantaleão, Guapenu, Taquara, Patauá, Santo Antônio, Tauary, Ponta das Pedras, Caranaí, Jauari, Paracuhuba, São Félix, Terra Preta de Murutinga, Ponciano, Boa Vista, Bom Futuro, Mutuquinha, Sisaima, Mura Tucumã, Jutaí, Jacaré, Gavião. As aldeias dos municípios de Manaquiri e Careiro Castanho não participaram por problemas de comunicação.

Organizações presentes: Conselho Indígena Mura (CIM); Associação dos Produtores Mura de Autazes (APIMA), Organização dos Estudantes Mura (OEIM), Organização dos Professores Mura (OPIM), Organização das Lideranças Indígenas Mura do Careiro da Várzea (OLIMCV), Conselho Indigenista Missionário (CIMI) Coordenador Regional da Fundação Índio/FUNAI, Sr. Edvaldo Oliveira), Grupo de Pesquisa Dabukuri - Planejamento e Gestão do Território na Amazônia (UFAM), do antropólogo Bruno Caporrino.

A assembleia ocorreu nos 3 dias, porém tivemos um pequeno incidente no final do primeiro dia e pela manhã do segundo dia.

Como parte da programação do segundo dia da proposta encaminhada e aprovada, constava a discussão do empreendimento e seus impactos nos meios bióticos e 
abióticos do componente indígena. Para essa programação foi convidado com autorização da diretoria do CIM, o coordenador do Estudo do Componente Indígena Mura do Projeto Autazes Amazonas (Processo FUNAI n ${ }^{\circ}$ 08620.045481/2013-10), antropólogo Cássio Noronha Inglês de Sousa, quem melhor poderia explicar os impactos por tê-lo elaborado.

Em nenhum momento, mesmo no Termo de nossa nomeação pela Juíza Dra. Jaiza Fraxe, houve a menção de que esse assunto não poderia ser abordado na assembleia. Para nossa surpresa, pela manhã do dia 20, recebemos por meio do antropólogo Bruno Caporrino uma mensagem do Procurador do Ministério Público Federal, Dr. Fernando Merloto de que não poderíamos discutir o empreendimento e seus impactos como constava na programação sob o risco de termos a assembleia invalidada. Essa mesma mensagem foi mostrada ao tuxaua Ilair Pereira dos Santos, presidente do CIM e posteriormente às demais lideranças presentes para decidirem o que fazer diante da situação. O antropólogo Bruno Caporrino também informou que o procurador havia enviado a mesma mensagem por e-mail para nós, mas como saímos de Manaus às $14 \mathrm{~h}$ do dia 19, não conseguimos acessar a internet depois desse horário, fato que foi confirmado no dia 23 de fevereiro quando tivemos acesso.

Nesse mesmo dia, à tarde, um dos participantes questionou a presença do antropólogo Cássio Noronha Inglês de Sousa, porque segundo ele, estava a serviço da Potássio do Brasil. Explicamos que o antropólogo estava a convite da organização com autorização da diretoria do CIM e que o mesmo era o coordenador do Componente Indígena cujo trabalho havia sido solicitado pela FUNAI, também confirmado pelo antropólogo que mostrou o Termo do Componente Indígena e ainda explicou que o documento ainda não havia sido protocolado devido a ACP movida pelo MPF.

Para resolver essas questões, conversamos com o Tuxaua Ilair Pereira dos Santos que convocou uma reunião no dia 20 de fevereiro às $20 \mathrm{~h}$ com todos os tuxauas das aldeias e diretoria do CIM para discutir o ocorrido e alteração da programação em função da mensagem do procurador. Nessa reunião, estavam presentes, cerca de 20 tuxauas, a diretoria do CIM e o advogado do CIMI, convidado das lideranças.

Após discussão e esclarecimentos sobre a questão, e em meio a confirmação de que todos os tuxauas e lideranças gostariam de conhecer o empreendimento e seus impactos pois ainda desconhecem, afirmaram que gostariam de ter essa discussão mesmo que fosse em outro momento e chegaram a considerar a possibilidade de ocorrer na assembleia do CIM. Mas alguns contra, argumentaram que na assembleia do CIM não seria estratégico porque poderia causar confusão e questionaram se poderiam solicitar essa discussão em outros momentos.

A resposta foi que de acordo com a Convenção 169 da OIT e Artigo 231 da Constituição Federal a Consulta Prévia, Livre e Informada é um direito e que eles têm au- 
tonomia para decidirem o que for melhor para o povo Mura de forma coletiva e não individual. Que não basta apenas alguns tomarem a decisão, mas TODOS conforme suas formas de organização política, social e cultural. No primeiro momento, as lideranças queriam continuar com a programação a revelia da informação do procurador invocando a sua autonomia e os princípios da convenção 169 da OIT e da CPLI. Argumentamos que essa decisão poderia inviabilizar tudo que havia sido feito até aquele momento.

Assim, decidiram por consenso que o antropólogo Cássio Noronha Inglês de Sousa poderia ficar não para expor impactos, mas apenas falar da elaboração do componente indígena e sua importância no processo durante $30 \mathrm{~min}$ com perguntas pelos participantes por mais 30 minutos. Dessa forma, retiramos de pauta a discussão do empreendimento e seus impactos, deixando para outras oportunidades ou durante $o$ processo de CPLI.

A exposição do antropólogo Cássio Noronha Inglês de Sousa foi tranquila embora algumas perguntas, que mesmo que tivesse sido explicado que não poderíamos entrar na questão dos impactos, foram feitas, mas não respondidas conforme orientação.

\subsection{Discussões e Dúvidas sobre a Consulta Prévia}

Na manhã do primeiro dia, 20 de fevereiro de 2018, foi realizada a apresentação de todas as delegações das aldeias e instituições presentes naquele dia, pela diretoria do CIM, pois algumas iriam chegar à tarde.

No final da manhã, iniciou-se a apresentação por mim explicando o que estamos fazendo, o porque e quem somos. Explicamos o objetivo da assembleia e que não se tratava da consulta prévia direta como muitos acreditavam e que estavam dispostos a tomar a decisão sobre o empreendimento. Na sequência com o apoio da advogada Carla Cetina Castro que faz parte do laboratório Dabukuri começamos a expor as seguintes questões conforme a programação usando exemplos dentro do contexto social cultural e territorial dos Mura para facilitar o entendimento. As questões foram: Sobre o que trata a Convenção 169 da OIT? Quais as leis que tratam da Consulta Prévia? O que é Consulta Prévia? Como e quando deve ocorrer? Qual a importância da Consulta Prévia aos Povos Indígenas? Qual a diferença entre audiência pública e Consulta Prévia? Quais os instrumentos e procedimentos usados para a Consulta Prévia? Quais as características da Consulta Prévia? Quais as diferenças entre protocolo e consulta prévia? Quem deve participar? Quais povos foram consultados? Como foi o processo? Quais resultados? 
A apresentação continuou pela tarde quando iniciamos um breve debate para tirarmos algumas dúvidas sobre a apresentação. Perguntas como "Existe a possibilidade do governo desrespeitar a decisão tomada na consulta Prévia?”; O que vai acontecer no caso da exploração mineral? Quem será penalizado se a consulta for desrespeitada? foram feitas até que tivemos o incidente sobre a presença do antropólogo Cássio Noronha Inglês de Sousa, contestada por um dos participantes que acabou por postergar a discussão em grupo que seria logo após.

O clima foi de tensão, mas resolvido e intermediado pela profa. Ivani Faria e pelo tuxaua Ilair Pereira dos Santos, presidente do CIM. As respostas das questões foram discutidas e entendidas e a programação do dia encerrada após a apresentação cultural das danças tradicionais.

No segundo dia, 21 de fevereiro de 2018, as atividades iniciaram com a apresentação do antropólogo Cássio Noronha Inglês de Sousa esclarecendo sobre o processo de contratação da sua equipe pela FUNAI para realizar o estudo do Componente Indígena, como foi realizado, quais as aldeias da área de influência direta e sua importância dentro do Estudo de Impacto Ambiental exigido pela legislação ambiental brasileira.

Após sua exposição alguns participantes levantaram algumas questões, mesmo sob a orientação inicial do presidente do CIM, para não fazerem perguntas sobre o empreendimento e impactos. Estas não foram respondidas e nem discutidas na assembleia.

- O prof. Gilberto dos Santos Pereira, diz que o Estudo do Componente indígena é importante e deve ser conhecido por todos e pergunta se há possibilidade de uma reunião específica para entendê-lo.

- Kleber Prado perguntou se a Silvinita vai ser retirada independente da decisão dos Mura.

- Estélio Pereira questionou se há possibilidade de haver uma reunião só para tratar dos impactos do empreendimento.

- Adílio Souza perguntou sobre a distribuição dos Royalties e como a silvinita será explorada.

- Claudio Filho questionou se tem como designar alguém da FUNAI de Manaus para acompanhar a Consulta Prévia.

- Wagner questionou por que apenas 04 aldeias participaram do Estudo do Componente Indígena.

- O prof. Roni Braga da Silva argumentou de que forma poderia aprofundar o conhecimento sobre o Estudo do Componente Indígena nas aldeias.

Posteriormente aos questionamentos, o antropólogo Cássio Noronha Inglês de Sousa não respondeu às perguntas sobre os impactos e empreendimento e explicou 
que o acesso público ao componente indígena somente seria possível após ter sido protocolado, o que não ocorreu devido a Ação Civil em curso.

Esclareceu que no Termo de Referência da FUNAI constavam apenas duas Terras Indígenas, que a equipe responsável pela elaboração do ECI resolveu inserir mais duas comunidades, do Lago de Soares e vila de Uricurituba e que tinha que seguir o referido termo. Informou ainda que houve reuniões para compartilhar os resultados do estudo, mas com pouca participação.

Os Mura consideraram ser insuficiente a abrangência do ECI apesar de serem estas as especificações que constavam no termo de referência elaborado pela FUNAI. Posição que também partilhamos, ao se considerar o porte do empreendimento - evidenciado pela quantidade de minerais que serão movimentados, de resíduos produzidos e de trabalhadores necessários para implantação e operação - a diversidade de impactos sociais e culturais que esses empreendimentos promovem em territórios indígenas e o potencial de agravamento de conflitos territoriais. É necessário ressaltar ainda que a inclusão de somente 4 comunidades para a avaliação de impactos ambientais frente ao povo Mura é uma afronta à sua forma de organização social e aos seus processos de governança, fato que é facilmente evidenciado quando observamos que em seus processos de decisão mais de 40 comunidades são convidadas, como o que ocorreu nesta assembleia (Figura 2).

Temos de lembrar que o termo de referência elaborado pela FUNAI é um ato administrativo, parte do processo de licenciamento ambiental que irá impactar diretamente os territórios indígenas, fazendo jus aos direitos de consulta e participação. Portanto, deve ser respeitado o direito de autodeterminação do povo Mura quando este reconhece coletivamente a insuficiência deste ECI, que foi elaborado tendo por base a avaliação do impacto em somente 4 comunidades indígenas.

Observa-se que a delimitação da abrangência adotada pelo termo de referência do ECI teve como base o raio de $10 \mathrm{Km}$ estabelecido pela portaria interministerial 60/2015 e por este motivo acabou incluindo somente as Terras Indígenas Paracuhuba e Jauary. Todavia, de acordo com a Escola de Direito da FGV, esses parâmetros devem ser apenas o mínimo observado, de forma que sejam interpretados como referências, mas sem descaracterizar o dever-ser dos estudos de impacto ambiental. Quaisquer impactos ambientais que possam ser previstos precisam ser considerados, sejam seus efeitos isolados, cumulativos ou sinérgicos. (FGV, 2020)

O termo de referência do ECI, além de não observar a complexidade da organização social do povo Mura e o potencial dos impactos socioambientais sobre outras terras indígenas, também desconsiderou a existência de terras indígenas Mura que ainda não foram demarcadas, violando assim o direito originário desse povo sobre as terras que tradicionalmente ocupam. Assim fica evidente a falha na elaboração do 
termo de referência do ECI e por conseguinte a sua ilegitimidade devido seu vício de origem, devendo ser corrigida sob pena de invalidar o estudo.

Terminado o adendo sobre este ponto específico, retornamos ao relato dos acontecimentos e da metodologia de discussão adotada na assembleia. A discussão foi finalizada pela manhã e em seguida houve a divisão dos participantes em 7 grupos para responderem às seguintes questões: $O$ que entendemos? o que não entendemos? o que precisamos saber mais? que levou a parte da manhã e apresentação dos resultados à tarde.

Os grupos foram coordenados pelos professores Mura que foram previamente orientados pela profa. Ivani Faria de como deveriam fazer as discussões e deixar livre para todos os tipos de perguntas e questionamentos sobre a Consulta Prévia e seus instrumentos, objeto da assembleia. Material de apoio com cópias de alguns protocolos elaborados pelos Waiapi, Munduruku, Xingu etc., foram distribuídos para os grupos para que pudessem ver e saber como foram feitos.

A pedagogia da pergunta (problematização) permite criação de espaço de construção dialógico e coletivo, capaz de identificar as compreensões e proporcionar ambiente fecundo para a geração de novas ideias e propostas. Os trabalhos em grupo, que foram fundamentados nesse princípio pedagógico, também permitiram que os próprios membros dos grupos mediassem a aprendizagem aos "parentes" durante os trabalhos em grupo, explicando os conceitos e princípios da consulta a partir de seus contextos locais e exemplos cotidianos, tornando o processo de apropriação em relação aos direitos da consulta prévia mais fluído e de fácil apreensão.

As questões mais levantadas pelos 7 grupos foram:

- O protocolo tem validade? Vai receber assinatura? De quem?

- O protocolo pode ser reformulado? em quanto tempo?

- O protocolo aprovado ficará com quem?

- O protocolo sendo aprovado passa a fazer parte da Lei orgânica do município?

- Porque o Estudo do Componente Indígena foi feito antes da Consulta?

- Quem vai autorizar para ficar ativo o protocolo da consulta prévia?

- Como podemos criar uma cartilha sobre a exploração mineral?

- O protocolo pode ser barrado pelo governo?

- Os direitos indígenas vão ser respeitados depois da exploração?

- Porque os representantes da FUNAI de Brasília não vem consultar e nem ouvir o povo Mura sobre a exploração da Potássio?

- Há possibilidade de criar uma comissão para acompanhar a realização da consulta prévia e depois sua execução? 
- O que é consulta prévia? Qual a diferença entre protocolo e consulta direta? Precisamos entender melhor.

- Quanto tempo vai levar para fazer o protocolo? Podemos fazer os 2?

- Qual o mais importante? qual fazer primeiro?

- Se não aceitarmos a exploração, a quem recorrer? A quem podemos pedir ajuda?

- No protocolo a decisão será conjunta, por todos ou apenas pelas lideranças? Serão realizadas reuniões em todas as comunidades?

- Vai ter momento de falar sobre os impactos? Quando?

- O protocolo aprovado servirá para as demais tomadas de decisão do povo Mura?

- Qual o prazo mínimo para o protocolo estar pronto?

- Podemos fazer tanto o protocolo quanto a consulta direta?

- Quanto tempo vai demorar a elaboração do protocolo? Como será feito? Quantas pessoas podem participar por aldeia? Quais são as instituições que podem participar?

- E quanto tempo dura, quem pode participar da consulta direta?

- Quanto tempo deve ocorrer a consulta direta?

No final da tarde, em reunião da equipe Dabukuri, após análise das questões acima e devido a solicitação dos participantes, foi definido que o Dr. Vanildo Pereira da Silva Filho e o antropólogo Bruno Caporrino participariam como convidados para apoiar nas discussões na manhã do dia 22 de fevereiro com a seguinte organização: Dr. Vanildo faria o esclarecimento sobre o que é consulta prévia, seus instrumentos e sua importância; Bruno Caporrino sobre a discussão do protocolo de consulta, cuja proposta foi discutida e protocolada, e assim esclarecendo a metodologia, quem participará, onde serão as reuniões e demais questões inerentes ao protocolo e por fim, a profa Ivani Faria fecharia com as esclarecimentos mais detalhados das questões levantadas e abordadas pelos convidados.

O terceiro dia, 22 de fevereiro de 2018, teve início com o esclarecimento feito pela profa Ivani Faria mais uma vez, sobre o objetivo da assembleia que era definir os instrumentos da Consulta Prévia, Livre e Informada e que não representa a potássio do Brasil, que são da Universidade Federal do Amazonas/UFAM, nomeados pela justiça federal para a realização do trabalho. O planejamento do dia anterior foi mantido e após os esclarecimentos de cada convidado foi aberto a discussões para os participantes.

Como apoio na discussão do protocolo pelo antropólogo Bruno Caporrino, foi realizada a leitura da metodologia proposta para sua elaboração e questionamos se 
todos a conheciam e se a entendiam. Houve o questionamento novamente de quando iria começar e se outras aldeias que não estavam na proposta poderiam ser inseridas.

O antropólogo Bruno Caporrino afirmou que o protocolo pode ser realizado em 01 ano, e por isso cortou algumas atividades da proposta apresentada e informou que é possível a inserção de outras aldeias.

Os participantes também destacaram a preocupação com o tempo para elaboração do protocolo e com a consulta prévia e que a discussão sobre o empreendimento deveria ser realizada também nas escolas.

Mais uma vez, questões como "A quem recorreremos se o governo não respeitar o protocolo? Quando vamos conhecer melhor o empreendimento? surgiram novamente.

Todos os palestrantes e a profa Ivani Faria foram unânimes em afirmar que, quem decide como, quando, quem, o que fazer, são eles de forma coletiva assegurando o direito e a autonomia dos povos conforme as legislações vigentes nacionais e internacionais.

No final de todos os esclarecimentos, os participantes foram divididos novamente em 7 grupos, sob a coordenação dos professores Mura, para definirem sobre os instrumentos da consulta prévia. Mais uma vez, um conjunto de perguntas foram discutidas de forma coletiva.

As discussões em grupo foram sobre: 1 - Qual(ais) o(s) instrumento(s) deve(m) ser utilizado(s) no processo de Consulta Prévia do empreendimento? Porque? 2 - Querem fazer o protocolo da Consulta Prévia? Quando deve começar os trabalhos para fazer o protocolo? 3 - Tem alguma aldeia que deve ser inserida na proposta do protocolo? Qual? 4 - Quando deve começar as atividades da consulta prévia? 5 - Quais outras propostas vocês querem inserir?

À tarde, os grupos apresentaram os resultados das discussões e foram unânimes nas respostas da pergunta número 1: os dois instrumentos devem ser realizados, protocolo e consulta prévia direta. Seis dos sete grupos afirmaram que a consulta prévia deveria ser realizada depois do protocolo e apenas um ao mesmo tempo da elaboração do protocolo.

Quanto à discussão de quanto tempo depois da realização do protocolo deveria iniciar o processo da consulta prévia, houve várias sugestões como por exemplo de 1 mês a 6 meses após. Após a sistematização das respostas houve discussão e defesa das que havia várias sugestões e após ampla discussão foram aprovadas por aclamação e por consenso. Logo depois, a ata da assembleia foi lida e aprovada por todos, resultando no final da assembleia da pré-consulta à consulta prévia. 


\subsection{Resultados da Assembleia}

A assembleia teve como resultado definições coletivas do povo Mura para orientar o processo de consulta prévia livre e informada do povo Mura frente ao projeto Autazes, proposto pela empresa Potássio do Brasil, sendo elas:

a) Realização do processo deconsulta prévia do povo Mura em duas etapas, devendo ser primeiramente elaborado o Protocolo de Consulta Préviapara posteriormente, realizar a CPLI referente ao empreendimento de extração de Silvinita no Município de Autazes por parte da Potássio do Brasil. A elaboração do protocolo de consulta não é condição sine qua non para a realização da consulta prévia, livre e informada. Mas o povo Mura entendeu que era essencial fazê-lo como parte desse processo;

b) A elaboração do protocolo deveria ser iniciada no mês de abril de 2018;

c) Definiram que a metodologia de elaboração do protocolo deveria seguir as diretrizes propostas pelo antropólogo Bruno Caporrino, sendo: uma Oficina Geral de abertura na comunidade de Soares, reuniões locais, seguida de 6 reuniões Regionais (Região Madeira, tendo Josefa como aldeia de referência; Região Rio Preto, tendo Trincheira como aldeia de referência; Região da Boca da Estrada, tendo Moyray como aldeia de referência; Região de Careiro da Várzea, tendo Sissaima como aldeia de referência; Região de Murutinga, tendo Murutinga como aldeia de referência; Região de Paraná do Autaz-açu, tendo Soares como aldeia de referência), seguida de uma reunião final na aldeia Cuia e assembleia para aprovação final na aldeia de Murutinga.

d) Para além das comunidades listadas na proposta do protocolo elaborada pelo antropólogo Bruno Caporrino no âmbito da Ação Civil Pública (processo número 19192-92.2016.4.01.3200) foram incluídas as comunidades Paiol, Vista Alegre e Fortaleza, do município de Manaquiri; as comunidades Renascer, Piranha e Marinheiro, do município de Careiro Castanho; e a comunidade de Paracanatuba, do município de Autazes como participantes da elaboração do protocolo de consulta;

e) Os Mura presentes na assembleia indicaram o mês de junho de 2019 como período previsto para início da consulta prévia livre e informada referente ao empreendimento de extração de silvinita no Município de Autazes por parte da Potássio do Brasil. Momento este em que seriam amplamente informados sobre o empreendimento e seus impactos. Esta data foi estimada considerando que neste período o protocolo de consulta já haveria sido elaborado, difundido e apropriado por todos. Todavia o cronograma foi atrasado pois o protocolo de consulta foi finalizado em junho de 2019 e depois houve a pandemia de Covid-19, que impossibilitou a realização do processo de consulta;

f) A criação de uma comissão de acompanhamento do protocolo e da consulta 
prévia, a ser constituída na primeira oficina de elaboração do Protocolo, com caráter fiscalizador, não deliberativo;

g) Definiram que seria importante a participação de um técnico da FUNAI de Brasília, da Diretoria de Proteção Territorial (DPT) e de um técnico do IPHAN bem como o apoio de um represente do Departamento de Educação Escolar Indígena da UFAM e participação do CIMI no processo de construção do protocolo e da consulta prévia:

h) Solicitaram que a justiça federal determinasse que as instituições Secretaria Estadual de Educação do Estado do Amazonas (SEDUC) e Secretaria Municipal de Educação (SEMEC) dos municípios de Autazes, Careiro da Várzea, Careiro Castanho e Manaquiri e o Distrito Sanitário Especial Indígena/DSEI não cortassem os salários dos professores e profissionais indígenas de saúde que fossem indicados para participar da consulta prévia.

\subsection{Avaliação com diretoria do CIM no final da Assembleia}

Por volta das 20 h, realizamos uma breve avaliação com participação de alguns membros do CIM, Tuxaua Ilair Pereira dos Santos, Raimundo Nonato Marques e Josenildo Pereira de Souza. Todos gostaram da forma como a assembleia foi organizada e afirmaram que os objetivos foram atingidos com ampla participação das lideranças e aldeias. O espaço do centro comunitário comportou bem os participantes. Houve segurança com alimentação, transporte e combustível conforme combinado.

\subsection{Análise da Assembleia}

Desde a primeira reunião de planejamento da Pré Consulta à Consulta Prévia no dia 05 de janeiro de 2018, percebemos que o povo Mura mesmo após as discussões sobre a elaboração do protocolo da consulta prévia tinha dúvidas sobre o que é Consulta Prévia, seus instrumentos e procedimentos porque até o primeiro dia da assembleia ainda pensavam que o objetivo dela era decidir sobre a realização do empreendimento em Autazes. Isso foi esclarecido durante a assembleia, mas sugerimos que esse assunto devesse ser aprofundado durante a elaboração do protocolo para melhor esclarecimento e compreensão do povo Mura.

Existe uma demanda das lideranças e participantes da assembleia, destacados em vários momentos, sobre a necessidade de discussão do empreendimento da exploração da silvinita e seus impactos. Tal desconhecimento vem causando muita tensão e equívocos de entendimento por parte do povo Mura, uma vez que a Consulta Prévia deve ser consentida, livre e informada. Assim, sugerimos que o MPF e a $1^{\text {a }}$ Vara em 
parceria com o CIM, em momento que melhor convier ao povo Mura, promovesse discussões sobre o empreendimento e seus impactos com profissionais qualificados para que informados e esclarecidos possam tomar as decisões mais acertadas como povo.

Todos os participantes da assembleia concordaram com a realização dos 2 (dois) instrumentos, o protocolo e a consulta direta pois entenderam que o protocolo assegura seus direitos diante de qualquer decisão administrativa ou legislativa e que a consulta prévia é o exercício e materialização desse direito. Também recomendamos que as aldeias indicadas pela assembleia fossem incorporadas na proposta de elaboração do protocolo de consulta prévia feita pelo antropólogo Bruno Caporrino.

O início dos trabalhos para elaboração do protocolo de consulta deveria ocorrer o mais rápido possível pois não é uma estratégia o prolongamento dessa discussão e nem da consulta prévia pois quem mais sofrerá nesse processo é o povo Mura diante das pressões que podem sofrer por todos os lados.

Recomendamos que a FUNAI e COIAB deveriam acompanhar a construção da consulta prévia e de seus instrumentos integralmente, e por fim, que o MPF e a $1^{\mathrm{a}}$ Vara, atendessem a solicitação de inclusão do IPHAN na discussão da Consulta Prévia.

O Protocolo de Consulta e Consentimento do Povo Indígena Mura de Autazes e Careiro da Várzea - Amazonas intitulado "Trincheiras: Yandé Peara Mura” foi elaborado e entregue formalmente à justiça federal no dia 12 de agosto de 2019. Assim, para o Povo Mura o processo de construção da CPLI, terá início com uma Assembleia Geral, onde eles decidirão se existirá um procedimento simplificado ou um mais completo, e será finalizado com a tomada de decisão por eles.

\section{CONSIDERAÇÕES FINAIS}

O processo de planejamento e construção da Assembleia do Povo Mura que foi denominada "Assembleia da Pré-Consulta à Consulta Prévia” foi uma experiência que permitiu levantar vários aspectos importantes no âmbito do direito à CPLI reconhecido na Convenção 169 da OIT, levando em consideração todo o panorama em que se encontrava o processo judicial e a pressão que os Mura sofriam constantemente pela exploração de silvinita em Autazes.

Nos corpos normativos onde se encontra regulamentada a CPLI, se estabelecem princípios e diretrizes que permitem aplicar este direito respeitando as especificidades dos povos. Muitas vezes isto representa um desafio para o sistema judiciário, as organizações indigenistas, a universidade e aos pesquisadores, pois a sociedade ocidental onde estes sujeitos se desenvolvem, estão acostumados que o direito crie modelos, parâmetros gerais que podem ser aplicados a vários casos específicos. 
O direito de CPLI é um direito humano que está em constante reinvenção e se adapta a cada caso específico quando uma medida administrativa ou legislativa afeta a um povo indígena, quilombola ou comunidade tradicional. A criação de modelos somente impõe uma lógica ocidental que não respeita o espírito deste importante direito. Quando se trabalha junto aos povos indígenas é fundamental desconstruir o pensamento, as metodologias, e a linguagem com que apresentamos não somente as decisões que afetaram a uma determinada comunidade, mas também a forma em que nos relacionamos com estes grupos sociais.

Ter a oportunidade de contribuir na Assembleia da Pré-Consulta à Consulta Prévia nos permitiu entender que o direito nem sempre tem todas as respostas, e que o direito de autodeterminação dos povos indígenas, quilombolas e comunidades tradicionais, assegurado na Convenção 169 da OIT, é o que deve prevalecer ante qualquer circunstância, pois estão se tratando da vida destes grupos sociais. São eles que entendem como funciona sua organização social, o uso do seu território e os caminhos adequados em que devem guiar seu desenvolvimento.

As metodologias utilizadas na elaboração dos Protocolos de CCPLI, assembleias de decisão e dos próprios processos de CPLI, devem ser participantes assegurando a ampla participação contemplando todos os povos e comunidades que serão afetados direta ou indiretamente. Tradicionalmente, as tomadas de decisão ocorrem por consenso e não por votação. É fundamental que estes expressem suas organizações sociais, os processos de tomada de decisão, e não devem estar determinados por interesses das empresas privadas, governos, universidade, organizações não governamentais ou parceiros que tenham ou não interesse nos megaprojetos.

$\mathrm{O}$ direito à CPLI incide sobre todo o processo de licenciamento do empreendimento, incluindo os Termos de Referências dos estudos de impacto ambiental, que devem ser elaborados a partir de discussões conjuntas, entre os sujeitos a serem afetados, suas representações político-sociais e os órgãos de governo responsáveis, nesse caso a FUNAI, para que não haja omissões, injustiças, processos no sentido de evitar maiores conflitos entre as partes e garantir a autonomia e os direitos dos povos indígenas.

É importante destacar que mesmo a Convenção 169 da OIT ofereça princípios e diretrizes gerais para discussão e construção da CPLI, dentre todos, a autonomia, não cabe a nós, universidades, ongs, consultores, empresas, sistema jurídico tentarem definir o que é a CPLI, seus procedimentos, onde e quando se inicia o processo pois quem deve dar o rumo e a direção a essa discussão são os sujeitos envolvidos no exercício dos seus direitos. 


\section{REFERÊNCIAS}

ANAYA, James. El derecho a la consulta previa en el derecho internacional. In. Encuentro extraordinario de la Federación Iberoamericana del Ombudsman. El derecho a la Consulta Previa de los Pueblos Indígenas. El rol de los ombudsman en América Latina. Lima, 2013. Defensoría del Pueblo, 2013. p. 19-25.

FARIA, Ivani. Metodologias participantes e conhecimento indígena na Amazônia: Propostas interculturais para a autonomia. In: SANTOS, Boaventura de Sousa et al. (org.). Epistemologias del Sur - Epistemologias do Sul. 2018.

FGV. Parâmetros para a Consulta e para o Respeito dos Direitos de Povos Indígenas e Comunidades Tradicionais Atingidas por Empreendimentos de Infraestrutura. São Paulo: Clínica de Desenvolvimento Sustentável da Escola de Direito de São Paulo da FGV, 2020.

MAZARIEGOS, Monica. Derecho a la consulta y disenso. Por el uso contrahegemónico del derecho. 2014. 634 f. Tese (Doutorado em Direitos Humanos) - Universidad Calor III de Madrid, Instituto de derechos humanos "Bartolomé de las Casas”. Getafe.

OIT, Organização Internacional do Trabalho. Convenção 169 Convenção $\mathbf{n}^{\circ} 169$ da OIT sobre Povos Indígenas e Tribais. ONU: 1989. Disponível em: https://www. ilo.org/wcmsp5/groups/public/@ed_norm/@normes/documents/publication/ wcms_100907.pdf. Acessado em: 07 de dezembro de 2020

SILVA, Luiz Fernando Villares e. (Org.). Coletânea da legislação indigenista brasileira. Brasília: CGDTI/FUNAI, 2008. 818p. 